\title{
PSP toxin analysis and discrimination of the naturally co-occurring Alexandrium tamarense and A. minutum (Dinophyceae) in Cork Harbour, Ireland
}

\author{
Nicolas Touzet ${ }^{1, *}$, Jose M. Franco ${ }^{2}$, Robin Raine ${ }^{1}$ \\ ${ }^{1}$ The Martin Ryan Institute, National University of Ireland, Galway, Ireland \\ ${ }^{2}$ U.A. Fitoplancton Tóxico, CSIC-IEO, Apto. 1552, Vigo, Spain
}

\begin{abstract}
A mixed community composed of a non-toxic form of Alexandrium tamarense and a paralytic shellfish poisoning (PSP) toxin-producing A. minutum develops on an annual basis in Cork Harbour, Ireland. The understanding of the ecological mechanisms that influence the population dynamics of these bloom-forming species is fragmentary, partly due to the difficulty in the discrimination between Alexandrium species in mixed phytoplankton assemblages by conventional light microscopy. During 2 surveys carried out in the estuary in July and September 2005, taxon-specific large subunit rRNA targeted probes were used in a whole-cell fluorescent in situ hybridisation assay to facilitate the detection and quantification of Alexandrium spp. in seawater samples. The Alexandrium spp. concentrations derived with molecular probes were on average half those obtained using an Utermöhl sedimentation chamber and calcofluor. Results showed the dominance of A. tamarense over A. minutum in July and an almost exclusive presence of A. minutum in September. Alexandrium spp. did not quantitatively dominate the total dinoflagellate assemblage and cell concentrations were

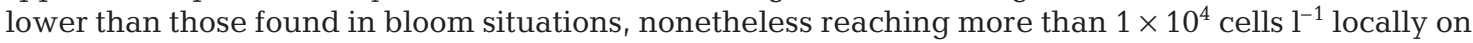
both occasions. The PSP toxins GTX3 and GTX2 were detected in all field samples, concentrations being associated with greater abundances of A. minutum in September. Despite probable inaccuracies inherent in the sampling methodology, the estimated intracellular toxin quotas in A. minutum were higher in the areas of the estuary that connected different water bodies and where cells may be subjected to regimes of high turbulence and rapid changes of salinity and temperature.
\end{abstract}

KEY WORDS: Alexandrium · FISH probes · PSP · Paralytic shellfish poisoning · Population dynamics · $\mathrm{HAB} \cdot$ Harmful algal bloom

\section{INTRODUCTION}

Economic and public health concerns have arisen with the apparent increase of the frequency and geographical distribution of harmful algal blooms (HABs) worldwide (Hallegraeff 1993, Hoagland et al. 2002). Nuisance blooms of phytoplankton can be a recurrent phenomenon in coastal waters and are often linked to local climatological condition and/or anthropogenic factors (Sorokin et al. 1996, Hallegraeff 2003). The distribution of $\mathrm{HAB}$ events in space and time is governed by the species-specific biological attributes of the causative organisms and site-specific oceanographic conditions. To protect public health and limit potential economic losses for the aquaculture industry, shellfish and phytoplankton monitoring programs have been implemented in various countries (Andersen et al. 2003). However, difficulties generally arise when the species of interest constitute minor components of the phytoplankton community and/or occur with morphologically similar organisms.

The cosmopolitan dinoflagellate genus Alexandrium includes several toxic species associated with HABs (Anderson 1998). Some species can synthesise potent neurotoxins and have been implicated in shellfish toxicity, the corresponding human intoxication syndrome 
being paralytic shellfish poisoning (PSP). The PSP toxin family contains more than 20 naturally occurring saxitoxin analogues (Luckas et al. 2003). These compounds can trigger neurological symptoms in humans after consumption of contaminated shellfish, which may be fatal in severe cases (Kao 1993, Garcia et al. 2004). The cellular toxicity of species depends on the composition of the toxin profile and of the concentration of each individual variant, and has been shown to vary as a function of the physiological status of cells (Cembella 1998). For example, several studies have shown that phosphate stress promotes PSP toxin production in A. minutum, a species often involved in toxic events in European coastal waters (Hansen et al. 2003, Lippemeier et al. 2003, Frangopulos et al. 2004). In the environment, Alexandrium populations are subject to various biophysical pressures that influence physiological processes such as growth, life cycle transitions and toxicity, and hence determine their distribution and abundance. A thorough understanding of Alexandrium spp. population dynamics is therefore necessary to facilitate the management of HABs and enable the prediction of their occurrence and toxicity.
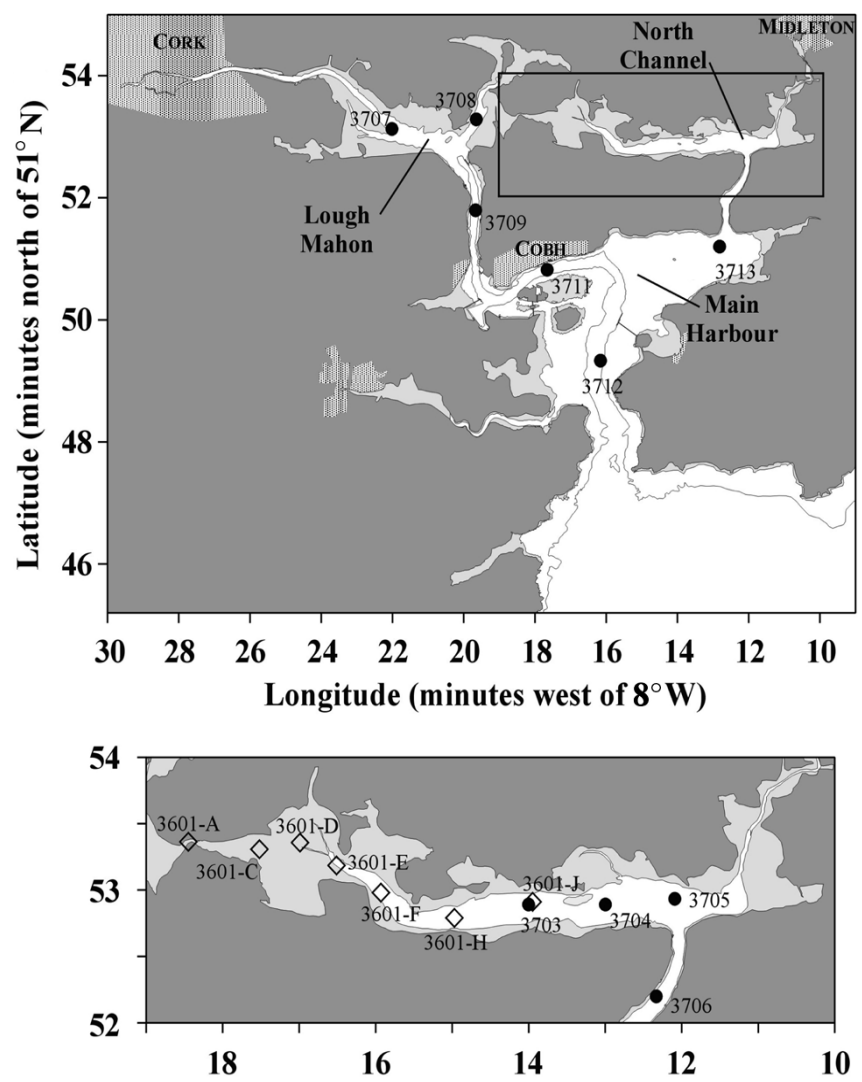

Fig. 1. Study area, including the stations sampled in July and September 2005. The $10 \mathrm{~m}$ isobath is shown; solid light grey zones highlight the areas exposed at low tide; hatched grey areas represent urban areas. The bottom panel shows an enlarged view of the North Channel area of Cork Harbour
The discrimination between Alexandrium species is complex and unreliable when performed by classic light microscopy. The precise identification of individual species requires the examination of morphological characteristics of the thecal plates that cover vegetative cells (Balech 1995). This procedure is particularly time consuming and partly explains why studies showing data on Alexandrium at the species levels in areas where several species co-occur are scarce in the literature (John et al. 2003, Gribble et al. 2005). A suite of techniques based on molecular biology has been adapted over the last decade to enable the detection and quantification of individual species in complex phytoplankton assemblages (Scholin et al. 1997, Anderson et al. 1999, 2005, Galluzzi et al. 2004). Most of those methods rely on the use of fluorescently labelled taxon-specific gene probes and antibodies. Whole-cell fluorescent in situ hybridisation (FISH) is a method that allows the detection of target species after the binding of taxon-specific probes to the ribosomes present in actively growing cells. A main advantage of FISH over other methods is that it preserves the structural integrity of Alexandrium vegetative cells and does not include in the results diploid cysts or refractory nucleic acids contained in dead cells and phycopellets.

In Ireland, Alexandrium spp. are commonly found along parts of the coastline during the summer months (Moran et al. 2005). Problems related with PSP toxicity in shellfish have, however, only been found on a regular basis in Cork Harbour, an estuary on the south coast of Ireland (FAO 2004). Here, morphogenetic and PSP toxin analyses carried out on cultured and field samples have shown the presence of a mixed assemblage of the non-toxic A. tamarense (West European ribotype) and the PSP toxin-producing species A. minutum (Touzet et al. 2006). The present study uses taxon-specific oligonucleotide probes to provide insights into the distribution and abundance of Alexandrium spp. in Cork Harbour during 2 surveys in summer 2005. A number of physicochemical variables were recorded in order to characterise the environment during sampling. Investigations on the spatial variability of PSP toxin concentrations and the possible link between in situ N:P ratios and intracellular PSP toxin quotas were also carried out.

\section{MATERIALS AND METHODS}

Study area and sampling. Field samples were collected on 19 July and 16 September 2005 in Cork Harbour, an inlet situated on the south Irish coast at $51^{\circ} 50^{\prime} \mathrm{N}, 8^{\circ} 17^{\prime} \mathrm{W}$ whose surface area is approximately $50 \mathrm{~km}^{2}$, with ca. $28 \%$ subjected to tidal influence 
(Fig. 1). Lough Mahon and the North Channel, 2 areas that connect to the main harbour by narrow waterways, both receive freshwater riverine inputs from the urban areas of Cork and Midleton respectively. The study comprised an east-west transect of stations in the North Channel of Cork Harbour in July 2005 (Fig. 1). A more comprehensive survey was carried out in September, which included stations in the North Channel, the main harbour and Lough Mahon (Table 1, Fig. 1).

Temperature and salinity data were measured in situ using a microprocessor conductivity meter (WTW, Cond197i). In September, a fluorometer (SeaTech) was also used for the vertical profiling of chlorophyll fluorescence. Surface and subsurface seawater samples were collected using a 51 bucket and a 51 Niskin bottle respectively. Samples of phytoplankton for microscopical analysis were collected by fixing $50 \mathrm{ml}$ of seawater with buffered formalin (1\% final concentration $\mathrm{v} / \mathrm{v})$. Samples for the detection and enumeration of Alexandrium spp. by whole-cell FISH consisted of 21 of seawater which were filtered using a hand pump through a $150 \mu \mathrm{m}$ mesh sieve and collected onto a $10 \mu \mathrm{m}$ mesh filter to remove large debris, which could mask target cells during the fluorescence analysis and retain Alexandrium spp. cells. The retained planktonic material was backwashed into $50 \mathrm{ml}$ polypropylene

Table 1. Details of the stations sampled during the surveys carried out in Cork Harbour

\begin{tabular}{|c|c|c|c|c|}
\hline Stn & Location & $\begin{array}{l}\text { Time } \\
\text { (local) }\end{array}$ & $\begin{array}{l}\text { Latitude } \\
\quad(\mathrm{N})\end{array}$ & $\begin{array}{l}\text { Longitude } \\
\text { (W) }\end{array}$ \\
\hline \multicolumn{5}{|c|}{19 July $2005^{a}$} \\
\hline 3601-A & North Channel & $16: 37$ & $51^{\circ} 53.363$ & $8^{\circ} 18.449$ \\
\hline 3601-C & North Channel & $16: 51$ & $51^{\circ} 53.307$ & $8^{\circ} 17.519$ \\
\hline 3601-D & North Channel & $16: 58$ & $51^{\circ} 53.357$ & $8^{\circ} 16.990$ \\
\hline 3601-E & North Channel & $17: 08$ & $51^{\circ} 53.185$ & $8^{\circ} 16.512$ \\
\hline 3601-F & North Channel & $17: 16$ & $51^{\circ} 52.980$ & $8^{\circ} 15.932$ \\
\hline 3601-H & North Channel & $17: 30$ & $51^{\circ} 52.790$ & $8^{\circ} 14.971$ \\
\hline 3601-J & North Channel & $17: 58$ & $51^{\circ} 52.911$ & $8^{\circ} 13.949$ \\
\hline \multicolumn{5}{|c|}{16 September $2005^{b}$} \\
\hline 3703 & North Channel & $10: 35$ & $51^{\circ} 52.880$ & $8^{\circ} 14.002$ \\
\hline 3704 & North Channel & 11:04 & $51^{\circ} 52.890$ & $8^{\circ} 12.998$ \\
\hline 3705 & North Channel & $11: 34$ & $51^{\circ} 52.933$ & $8^{\circ} 12.091$ \\
\hline 3706 & East passage & $12: 02$ & $51^{\circ} 52.199$ & $8^{\circ} 12.333$ \\
\hline 3707 & Lough Mahon & $13: 17$ & $51^{\circ} 53.127$ & $8^{\circ} 22.016$ \\
\hline 3708 & Lough Mahon & $13: 58$ & $51^{\circ} 53.284$ & $8^{\circ} 19.647$ \\
\hline 3709 & West passage & $14: 17$ & $51^{\circ} 51.794$ & $8^{\circ} 19.667$ \\
\hline 3711 & Main harbour & $15: 20$ & $51^{\circ} 50.820$ & $8^{\circ} 17.657$ \\
\hline 3712 & Main harbour & $15: 44$ & $51^{\circ} 49.331$ & $8^{\circ} 16.161$ \\
\hline 3713 & Main harbour & $16: 20$ & $51^{\circ} 51.200$ & $8^{\circ} 12.816$ \\
\hline \multicolumn{5}{|c|}{$\begin{array}{l}\text { aLow and high tides were at 10:37 and 16:28 h (local time), } \\
\text { respectively }\end{array}$} \\
\hline \multicolumn{5}{|c|}{$\begin{array}{l}\text { bLow and high tides were at 11:08 and 17:06 h (local time), } \\
\text { respectively }\end{array}$} \\
\hline
\end{tabular}

tubes with $0.22 \mu \mathrm{m}$ filtered seawater and fixed with formalin ( $5 \%$ final concentration v/v). Samples were kept in the dark until further processing on land. The same procedure, without the formalin fixation step, was used to obtain samples for PSP toxin analysis, which were stored in a refrigerated box until being processed further on land. Samples for the determination of chlorophyll a (chl a) concentrations were obtained after filtering $500 \mathrm{ml}$ seawater through GF/C filters which were then kept in darkness in a refrigerated box and stored at $-32^{\circ} \mathrm{C}$ in the laboratory until analysis. A further $50 \mathrm{ml}$ aliquot was filtered through $0.45 \mu \mathrm{m}$ syringe filters, kept in darkness in a refrigerated box and then stored at $-32^{\circ} \mathrm{C}$ in the laboratory for inorganic nutrient analysis (nitrate, nitrite, phosphate).

Morphology-based phytoplankton identification. Alexandrium spp. identification and quantification in taxonomic samples was performed using an Utermöhl sedimentation chamber (Utermöhl 1958) and results were used for comparison with the whole-cell FISH method. Armoured dinoflagellates were stained with calcofluor white (Fritz \& Triemer 1985) and examined with an inverted microscope (Olympus CKX-41) fitted with epi-fluorescence optics. Total Alexandrium spp. cell counts were carried out for each sample and precise species-specific discrimination was obtained for selected samples by examining at least 30 Alexandrium spp. cells. Identification at the species level was based on Balech's (1995) description of the genus and performed by rotating each Alexandrium spp. cell with a dissecting needle to observe the morphological characteristics of the thecal plates. Species were differentiated by the presence or absence of a ventral pore on the first apical plate $\left(1^{\prime}\right)$ and the shapes of the 6 th precingular $\left(6^{\prime \prime}\right)$ and posterior sulcal plates (sp) (Kofoid notation). Observations were made at

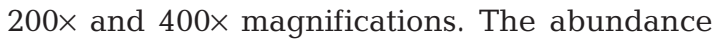
of selected common dinoflagellates was also determined in samples.

Oligonucleotide probe design and testing. The design and testing of taxon-specific oligonucleotide probes for Alexandrium minutum and $A$. tamarense was effectuated using cultures derived from resting cysts and/or vegetative cells isolated along the south and west coasts of Ireland. Cross-reactivity tests were carried out using a panel of 10 Alexandrium spp. and 6 dinoflagellate species commonly found in Irish coastal waters. DNA extraction, large subunit (LSU) rDNA polymerase chain reaction (PCR), sequencing, sequence alignment and probe design were performed as described in Touzet \& Raine (2007). Probes were commercially obtained (MWG Biotech) and synthesised 
with the 5'-end labelled with CY.3 and fluorescein isothiocyanate (FITC) for MinA (A. minutum Global Clade) and TamA (A. tamarense West European ribotype), respectively (Table 2). Upon receipt, concentrated probe stocks were diluted in double distilled water (final concentration $250 \mathrm{ng}^{-1}$ ), separated in $100 \mu \mathrm{l}$ aliquots and stored at $-32^{\circ} \mathrm{C}$ as working solutions.

FISH assay and epi-fluorescence microscopy. Once back on land, and always within $12 \mathrm{~h}$ of sampling, field samples taken for FISH analysis were centrifuged (4000 $\times g, 5 \mathrm{~min}$ ) and the supernatants were carefully discarded by aspiration. The remaining pellets were

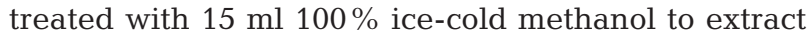
pigments and stabilise nucleic acids and then stored at $-32^{\circ} \mathrm{C}$ until analysis. Samples were stable for at least 8 mo in this state. Whole-cell FISH was carried out with the taxon-specific probes MinA and TamA according to a modified version of the protocol described in Miller \& Scholin (1998).

Aliquots of field samples preserved in methanol were placed onto $13 \mathrm{~mm}$ diameter polycarbonate membranes (1.2 $\mu \mathrm{m}$ pore size) held in a custom-made vacuum manifold (Miller \& Scholin 1998), and gentle vacuum was applied to remove liquid. Membranes were incubated at room temperature for $2 \mathrm{~min}$ with $400 \mu$ hybridisation buffer (5X SET, $20 \%$ formamide, $0.1 \%$ IGEPAL, $25 \mu \mathrm{g} \mathrm{ml}^{-1}$ polyadenylic acid). After further filtration, $400 \mu \mathrm{l}$ hybridisation buffer containing $500 \mathrm{ng}$ of each probe was added to each filter, which was then incubated in a dark chamber at $55^{\circ} \mathrm{C}$ for $60 \mathrm{~min}$. After filtration, membranes were washed for $1 \mathrm{~min}$ with $400 \mu \mathrm{l} 0.2 \mathrm{X} \mathrm{SET}$ at $55^{\circ} \mathrm{C}$ in the dark to eliminate excess unbound probes. Finally, the filters were carefully removed from the manifold and placed onto slides. Before mounting the coverslip, $5 \mu \mathrm{l}$ of a mix of calcofluor $\left(100 \mu \mathrm{g} \mathrm{ml} \mathrm{m}^{-1}\right)$ and DAPI $\left(3 \mu \mathrm{g} \mathrm{ml} \mathrm{m}^{-1}\right)$ were added onto each filter as well as $10 \mu$ l of SlowFade ${ }^{\circledR}$ Light Antifade (Molecular Probes) reagent to prevent the fading of the dyes' fluorescence.

Membranes were examined with a microscope (Olympus CKX-41) fitted with a U-RFL-T epi-fluorescence attachment and a $100 \mathrm{~W}$ Mercury lamp and 3way slider filter holder. The following filter combinations were used for the detection of the fluorescent signals: calcofluor and DAPI (355DF25 excitation filter,

Table 2. Alexandrium spp. taxon-specific oligonucleotide probes targeting sites in the D1-D2 domain of LSU rDNA

\begin{tabular}{|llc|}
\hline Target species & Probe sequence [5'-3'] & Fluorochrome $\left(5^{\prime}\right)$ \\
\hline A. minutum & MinA.TTATATGGTTGATGTGGGTGC & CY.3 \\
A. tamarense & TamA.TAGGTTTTGGCTGTGGGTGA & FITC \\
\hline
\end{tabular}

400DRLP dichroic mirror and 420 band pass barrier filter), FITC (485DF22 excitation filter, 505DRLP dichroic mirror and 530DF30 barrier filter) and CY.3 (525AF45 excitation filter, 560DRLP dichroic mirror and 595AF60 barrier filter). Observations were performed at $200 \times$ magnification by scanning the entire filter and counting all positive signals. Probe specificity was confirmed with calcofluor by a quick inspection of the general organisation of the Alexandrium spp. plate tabulation for each positive signal recorded.

PSP toxin analysis. Back on land, and within $12 \mathrm{~h}$ after collection, samples taken for PSP toxin analysis were centrifuged $(4000 \times g, 5 \mathrm{~min})$ and the supernatants discarded. Pellets were resuspended with $500 \mu \mathrm{l}$ of $0.05 \mathrm{M}$ acetic acid to extract toxins and kept at $-32^{\circ} \mathrm{C}$ until analysis. PSP toxin analysis was carried out by HPLC with post-column derivatisation using a $5 \mu \mathrm{m}$ LiChrospher $100 \mathrm{RP}-18(125 \times 4 \mathrm{~mm}$ inner diameter [i.d.]) column and fluorometric detection (FD). Analytical details were based on those of Oshima et al. (1989) with modifications by Franco \& Fernandez Vila (1993). The mobile phase for the first isocratic run, allowing the detection of saxitoxin (STX), neosaxitoxin (neoSTX) and decarbamoyl saxitoxin (dcSTX), was composed of $95 \%$ of $1 \mathrm{mM}$ octanesulfonic acid in a $10 \mathrm{mM}$ ammonium phosphate buffer ( $\mathrm{pH}$ 7.2) and $5 \%$ acetonitrile. The mobile phase for the second isocratic run, allowing the detection of gonyautoxins (GTXs) and their decarbamoyl forms (dcGTXs), was composed of $1.5 \mathrm{mM}$ sodium octanesulfonate in a $10 \mathrm{mM}$ ammonium phosphate buffer ( $\mathrm{pH}$ 7.0). The post-column effluent was oxidised at a reaction temperature of $65^{\circ} \mathrm{C}$ in a Teflon coil $(10 \mathrm{~m} \times$ $0.5 \mathrm{~mm}$ i.d.) with a solution of $7 \mathrm{mM}$ periodic acid in $0.5 \mathrm{M}$ phosphate buffer ( $\mathrm{pH} 9.0$ ) and an acidification solution of $0.5 \mathrm{M}$ acetic acid with flow rates of $0.4 \mathrm{ml}$ $\mathrm{min}^{-1}$ for both solutions. Fluorescence excitation and emission wavelengths were 330 and $390 \mathrm{~nm}$, respectively. PSP toxins were identified by comparison of their retention times with those of purified standards (National Research Council of Canada). Injection volumes of $10 \mu \mathrm{l}$ were used for each crude extract. The detection limits of toxin standards, with peak heights 3 times superior to the average background noise, were $0.015 \mathrm{ng}$ (STX), $0.010 \mathrm{ng}$ (dcSTX), $0.070 \mathrm{ng}$ (neoSTX), $0.030 \mathrm{ng}$ (GTX1), $0.007 \mathrm{ng}$ (GTX2), $0.007 \mathrm{ng}$ (GTX3) and $0.030 \mathrm{ng}$ (GTX4) under the selected conditions.

Chl $\mathrm{a}$ and nutrient analysis. Chl $\mathrm{a}$ concentrations were determined after overnight extraction with $90 \%$ acetone of the GF/C filters containing field material and subsequent fluorescence analysis with a Turner Designs Model 10-AU fluorometer (Strickland 
\& Parsons 1972). Dissolved inorganic nutrients, specifically nitrate and phosphate, were measured by flow injection using a LaChat QC 8000 automated analyser with computer-controlled sample selection and peak processing following the methods recommended by the manufacturer.

Statistical analyses. The statistical analyses were performed using SPPS Version 15.0 for Windows. Independent sample Student's $t$-tests were used to compare: (1) the contribution of Alexandrium minutum to the Alexandrium spp. community obtained with FISH and Utermöhl-derived methods; (2) the slopes of the linear regression curves derived in July and September from the Utermöhl and FISH count data; (3) the $A$. minutum intracellular PSP toxin quotas obtained in July and September; and (4) the PSP toxin content of $A$. minutum cells present in the narrow waterways connecting the different water basins in Cork Harbour.

Multiple factor analysis (MFA) (Escofier \& Pages 1990) was applied to the July and September data sets to assess the relationships between different variables. MFA explores the common structures present in several data sets in 2 steps. Principal component analyses (PCA) are first performed on each individual data set, which is then weighted by dividing all its elements by the square root of the first eigenvalue obtained from its PCA. The normalised tables are juxtaposed into a single matrix and subjected to a PCA again. The analyses were run for the following variables: temperature, salinity, Alexandrium tamarense and A. minutum concentrations, Prorocentrum spp. and Scrippsiella spp. concentrations, nitrate+nitrite and phosphate concentrations, PSP toxin concentrations and quotas, and in situ N:P ratio values. The final PCA was run for a correlation matrix in a Varimax rotation mode. The data sets were autoscaled by column standardisation prior to analysis.

\section{RESULTS}

\section{Oligonucleotide probe specificity}

A BLAST (www.ncbi.nlm.gov/BLAST/) search showed that the probes MinA and TamA were taxon-specific. Both probes showed high specificity towards their targets and strong positive signals were obtained after simultaneous hybridisation reactions of MinA and TamA with target cultured vegetative cells. In addition, the probes did not react with any of the other Alexandrium and dinoflagellate species tested. No matrix effect or apparent cross-reactivity with other phytoplankton species were observed during tests performed with field samples. The simultaneous use of DAPI and calcofluor proved particularly useful to con- firm the specificity of the probes and to discriminate fluorescent detritus present in the field material from target cells.

\section{July 2005 survey}

\section{Environmental data}

The survey was conducted at high tide. A salinity front was visible in the west end of the North Channel, distinct temperature/salinity profiles characterising the 2 water bodies (Fig. 2). Temperature was higher in the frontal area, probably reflecting warming water during the flood tide as it flows over the mudflats exposed at low tide. Thermal homogeneity of the water column was observed in the North Channel between Stns 3601-D and 3601-H. However, the marine influence was discernable in Stn 3601-J at the east end of the North Channel as salinity started rising and temperature decreasing between $5 \mathrm{~m}$ depth and the seafloor $(8 \mathrm{~m})$ (data not shown). Nitrate+nitrite and phosphate concentrations were consistently below 1 and $0.3 \mu \mathrm{M}$, respectively, east of the front (Fig. 2). However, values west of the front at Stns 3601-A and 3601-C were above 6 and $0.6 \mu \mathrm{M}$, respectively.
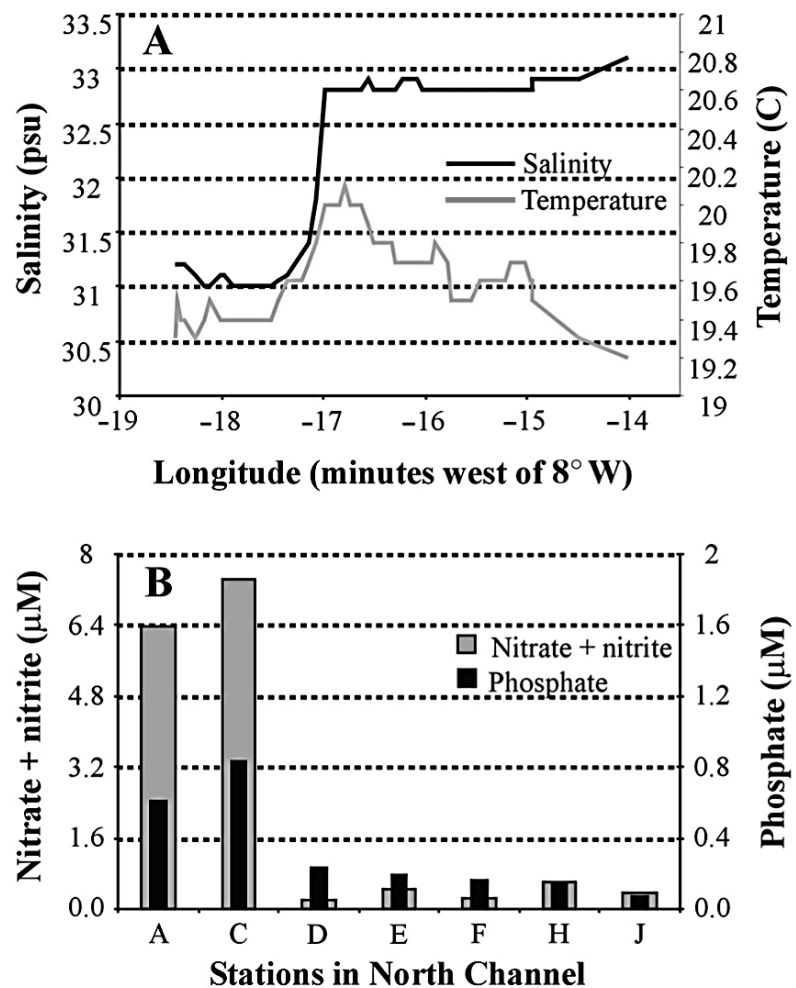

Fig. 2. Hydrographic data relative to the North Channel during the July survey. (A) Continuous record of surface temperatures and salinities. (B) Surface concentrations of dissolved nitrate+nitrite and phosphate at the stations sampled 
Distribution and abundance of Alexandrium spp. and selected dinoflagellates

Concentrations of Prorocentrum and Scrippsiella species were higher west of the front (Fig. 3). In contrast, Karenia mikimotoi was dominant in the eastern part of the North Channel with a maximum cell con-

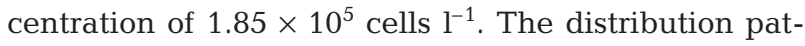
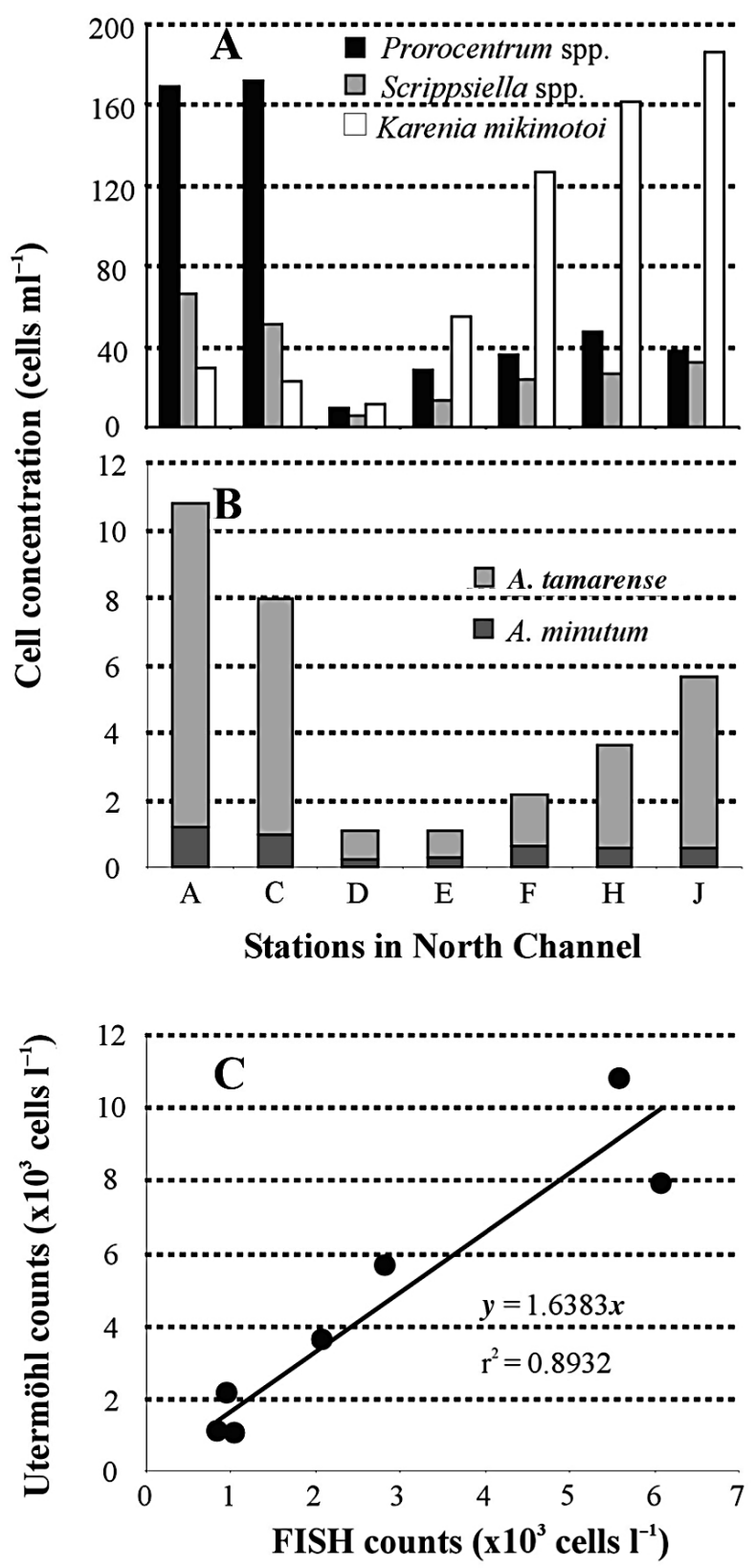

Fig. 3. Surface cell concentrations of (A) some dinoflagellates and (B) Alexandrium spp. at each station sampled. Cell abundances are based on counts performed with the Utermöhl method. (C) Relationship between the whole-cell FISH derived Alexandrium spp. concentrations and those obtained with the Utermöhl method tern of Alexandrium spp. mimicked that of Prorocentrum and Scrippsiella, although cell concentrations were much lower with a maximum of $10.7 \times 10^{3}$ cells $\mathrm{l}^{-1}$. Cell concentrations of Alexandrium spp. were vertically homogeneous along the North Channel area (data not shown).

The use of FISH probes allowed for fast and reliable species identification and enumeration. Alexandrium tamarense was largely dominant in all areas of the North Channel, forming an average of $80.8 \%$ (8.7 SD, $\mathrm{n}=7$ ) of the total Alexandrium spp. The contribution of A. minutum to the Alexandrium community was maximal in the middle portion of the study area. Cell concentrations derived with the whole-cell FISH method were compared to those obtained with the Utermöhl method (Fig. 3). The linear regression derived showed a good fit $\left(\mathrm{r}^{2}=0.89, \mathrm{p}<0.01, \mathrm{n}=7\right)$ but whole-cell FISH results underestimated the cell concentration by a factor of $\sim 1.6$. Counts performed at the species level with the Utermöhl method for selected taxonomic samples indicated that the proportions of A. minutum were significantly underestimated by on average $15.0 \%$ (3.3 $\mathrm{SD}, \mathrm{n}=5$ ) using the whole-cell FISH method $(t$-test: $\mathrm{p}<0.05)$.

\section{PSP toxin analysis}

PSP toxins were found in all the samples collected. The coefficient of determination obtained from the linear regression between PSP toxin levels and Alexandrium minutum concentrations was only 0.55 (Fig. 4), although toxin levels in samples were low and near the detection limits of the analytical equipment. Only GTX3 was quantifiable. Assuming that only A. minutum produced PSP toxins, the estimated average cellular toxin quota derived from the cell concentrations obtained using the whole-cell FISH method (see 'Discussion') was $2.9 \mathrm{fmol} \mathrm{cell}^{-1}(0.9 \mathrm{SD}, \mathrm{n}=7)$.

\section{September 2005 survey}

Environmental data

Physicochemical data are given in Fig. 5. Seawater in Lough Mahon, the North Channel and the main harbour was characterised by distinct temperature/ salinity profiles. Surface temperatures in Lough Mahon and the North Channel were close to $17^{\circ} \mathrm{C}$ and associated with lower salinities than in the rest of Cork Harbour, showing the freshwater influence of nearby rivers. Conversely, surface nitrate and phosphate concentrations were higher in Lough Mahon and in the North Channel than in the main harbour. However, the 


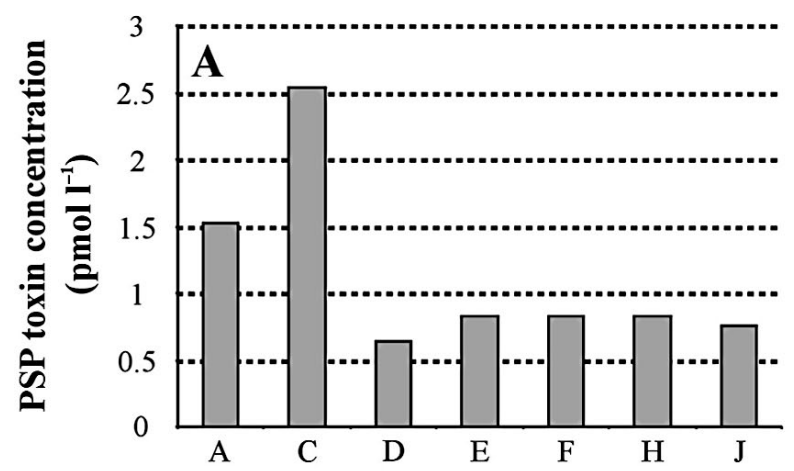

Stations in North Channel

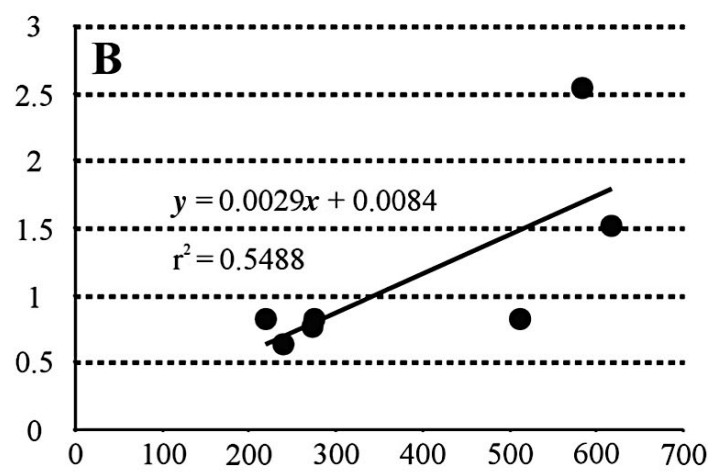

A. minutum FISH counts (cells $\mathrm{l}^{-1}$ )

Fig. 4. (A) Surface concentrations of PSP toxins in the North Channel and (B) relationship between FISH-derived Alexandrium minutum cell abundances and PSP toxin concentrations
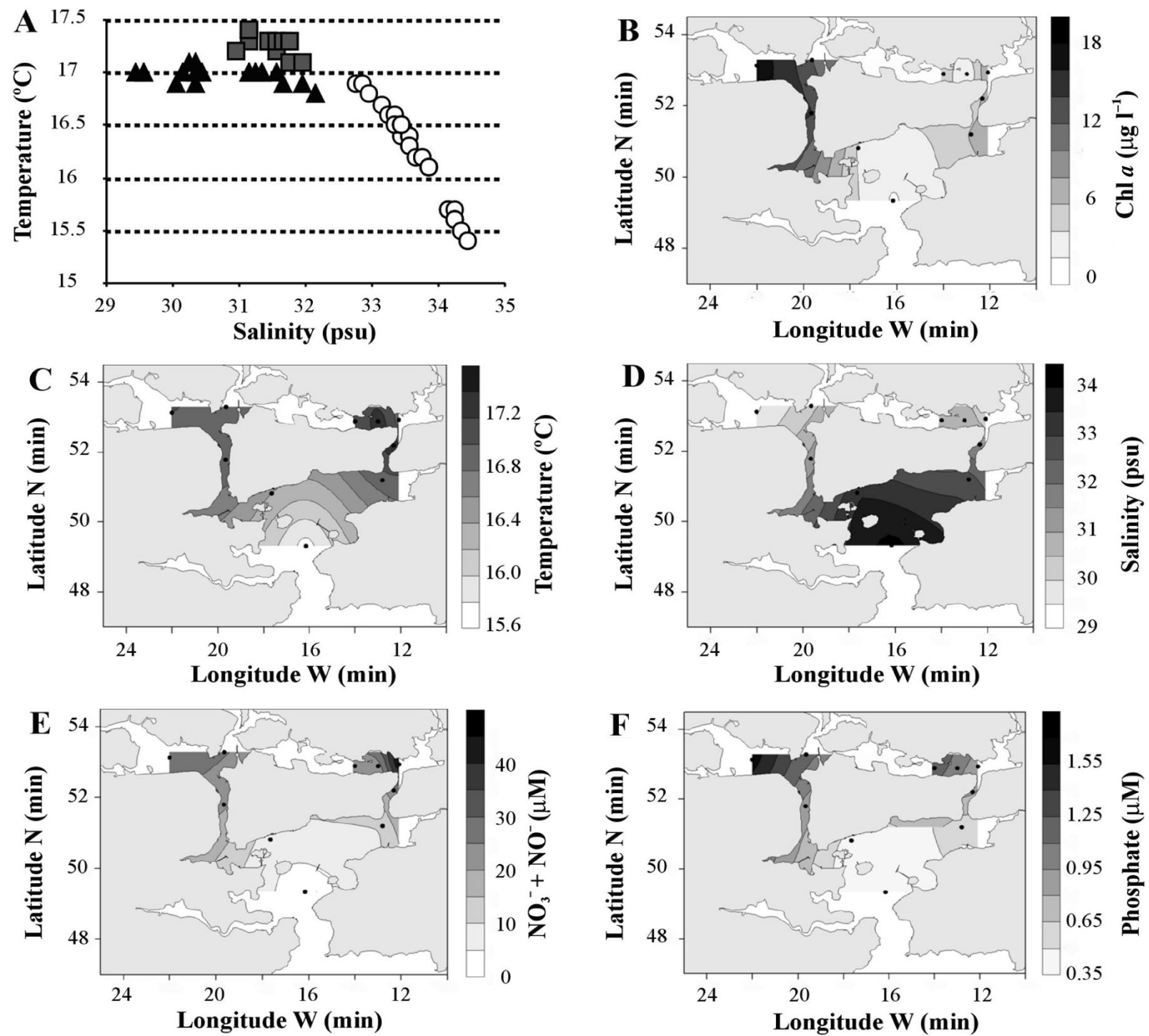

Fig. 5. Physicochemical characteristics of the seawater in Cork Harbour (ca. $51^{\circ} 50^{\prime} \mathrm{N}, 8^{\circ} 17^{\prime} \mathrm{W}$ ) during the September survey. (A) Temperature/salinity plot of data taken from Lough Mahon $(\mathbf{\Delta})$, the North Channel $(\square)$ and the main harbour (O). Respective surface distributions of (B) chl $a_{1}(\mathrm{C})$ temperature, (D) salinity, (E) nitrate + nitrite and (F) phosphate 
highest nitrate concentration was located at the east end of the North Channel, whereas the highest phosphate concentration was found at Stn 3707, the westernmost station in Lough Mahon in the river plume flowing from Cork.

Vertical profiles performed along a transect of stations in the North Channel highlighted the river influence in surface waters, characterised by lower temperature and salinity and a high nitrate concentration (Fig. 6). Phosphate concentrations along the transect were higher in the western stations of the North Channel and near the seafloor going towards the main harbour (Stn 3706). The maximum nitrate concentration was associated with the surface river plume as shown from the concentrated pool at Stn 3705.
Biological data

Surface chl a measurements showed an increased algal biomass in Lough Mahon and in the west end of the North Channel where nitrate and phosphate concentrations were also the highest (Fig. 5). Distinct distribution patterns were visible for Scrippsiella spp., Prorocentrum spp. and Gonyaulax spp. Scrippsiella spp. were essentially present along the length of the passage linking the North Channel and the main harbour. As in the July survey, the highest Prorocentrum spp. density was in Lough Mahon, but a moderate density patch was also visible at the south entrance of the channel connecting the main harbour to the North Channel near high tide. Gonyaulax spp. and Alexan-
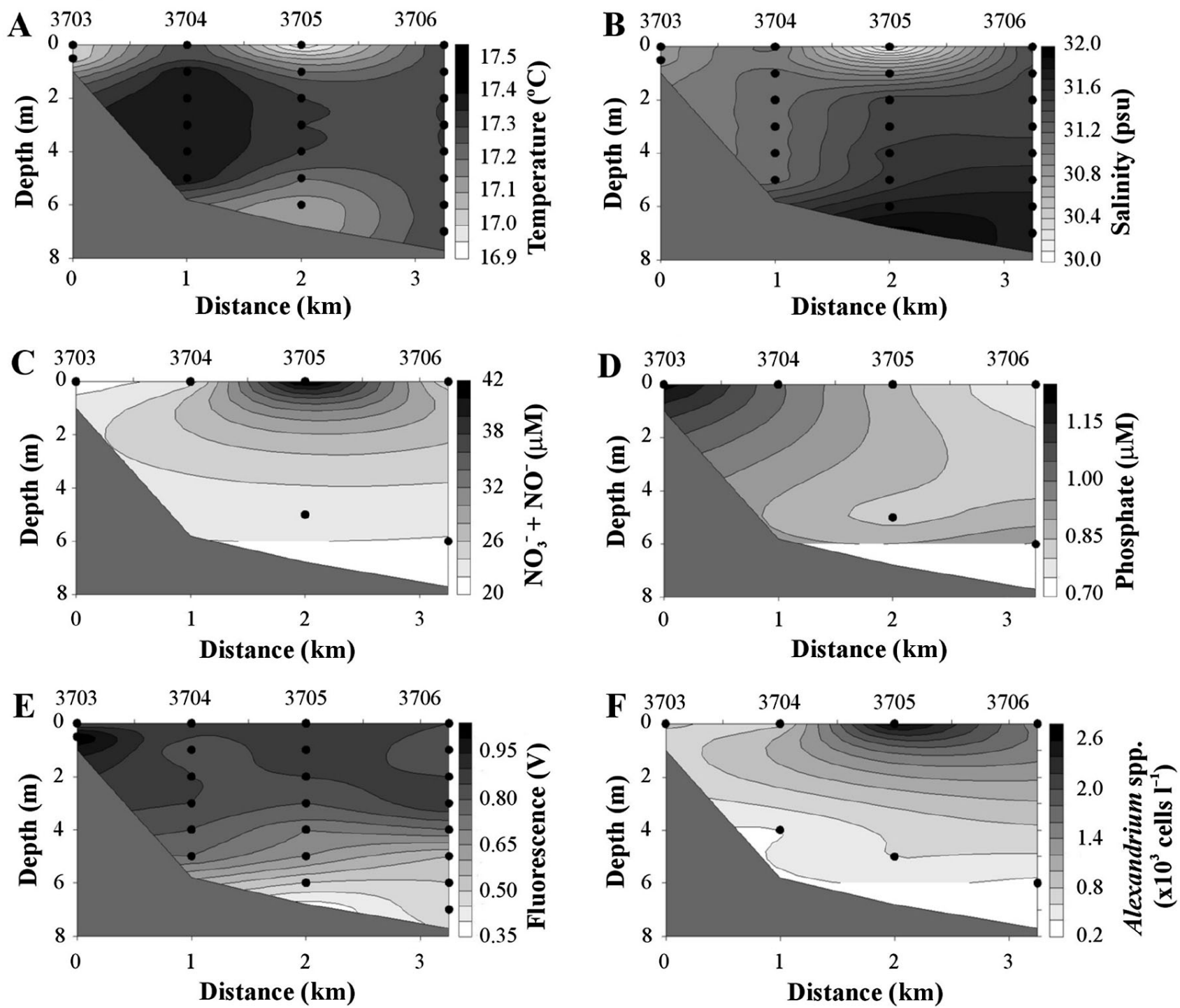

Fig. 6. Vertical distributions of (A) temperature, (B) salinity, (C) nitrate + nitrite, (D) phosphate, (E) chlorophyll fluorescence and (F) FISH-derived Alexandrium spp. concentrations along a transect of stations in the eastern region of the North Channel and towards the main harbour during the September survey 
drium spp. showed a similar distribution pattern with the maximum surface concentration observed at Stn 3705. The vertical transect of stations in the North Channel showed that Alexandrium spp. was more abundant at the eastern end, associated with a nitraterich and lower salinity water patch at the surface (Fig. 7).

The use of molecular probes for differentiating Alexandrium spp. showed the dominance of $A$. minutum, the contribution of $A$. tamarense being on average smaller than $3 \%$. The linear regression showed a good fit $\left(\mathrm{r}^{2}=0.83, \mathrm{p}<0.01, \mathrm{n}=9\right)$ between the wholecell FISH and the Utermöhl counting methods while removing data from the most litigious point (Stn 3705: 2575 and 16300 cells $1^{-1}$ with FISH probes and Utermöhl, respectively), the calcofluor-based technique giving higher cell estimation by a factor of 2.1, a result significantly higher ( $t$-test: $\mathrm{p}<0.05)$ to that obtained in July (Fig. 7).
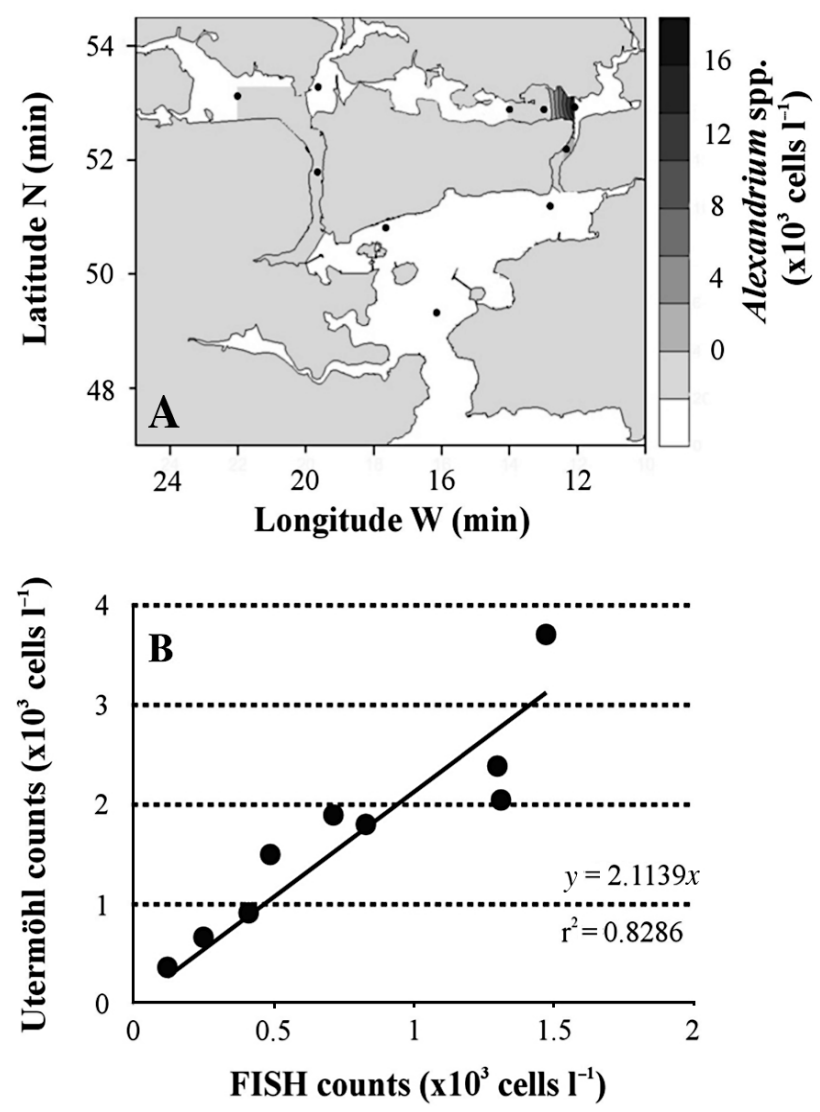

Fig. 7. Surface distribution of Alexandrium spp. (A) in Cork Harbour (ca. $51^{\circ} 50^{\prime} \mathrm{N}, 8^{\circ} 17^{\prime} \mathrm{W}$ ) during the September survey and (B) relationship between whole-cell FISH-derived Alexandrium spp. counts and those obtained with the Utermöhl method in September 2005. Data from Stn 3705 was omitted
PSP toxin analysis

Although the Alexandrium spp. concentrations were on average half those observed in July, PSP toxin concentrations were locally more than 10 times higher (mean \pm SD; July: $1.1 \pm 0.7$ pmol l $^{-1}, \mathrm{n}=7$; September: $10.9 \pm 10.3 \mathrm{pmol} \mathrm{l}^{-1}, \mathrm{n}=10$ ). A positive correlation was found between PSP toxins and A. minutum concentrations (Fig. 8). GTX3 was the dominant variant (>71\%) and the estimated average cellular toxin quota derived from the cell concentrations obtained with the wholecell FISH method was $10.3 \mathrm{fmol} \mathrm{cell}^{-1}$ (3.0 SD, n = 10), which was significantly higher than in July ( $t$-test: $\mathrm{p}<$ 0.05). A. minutum cells significantly appeared to be the most toxic in the waterways connecting Lough Mahon and the North Channel to the main harbour ( $t$-test: $\mathrm{p}<$ 0.05). Taking together the data from July and September, a positive correlation was visible between the estimated A. minutum PSP toxin quotas and in situ N:P ratios $\left(\mathrm{r}^{2}=0.60, \mathrm{p}<0.01, \mathrm{n}=16\right)$.

\section{Multiple factor analysis}

The MFA applied on the July and September autoscaled data sets resulted in 2 components that accounted for $73.9 \%$ of the total variance. The projections of the variable loadings on the principal components and score plots are shown in Fig. 9. Component 1 (CP1) was positively related to the following variables: nitrate+nitrite concentrations, in situ N:P ratios, Scrippsiella spp. and Alexandrium minutum concentrations and PSP toxin quotas and concentrations. Phosphate, Prorocentrum spp. and A. tamarense concentrations scored highest on Component 2 (CP2). Salinity was negatively related with both CP1 and CP2, whereas temperature contributed poorly to the 2 components. The constructed score plot did not reveal any clear clustering tendency but some stations could be segregated from the others. The stations closest to river outlets in both Loch Mahon (Stn 3707) and the North Channel (Stn 3705) were quite isolated on each component axis. Stations west of the front in the North Channel in July clustered together (Stns 3600-A and -C), as did the stations in the connecting channels in September (Stns 3706 and 3709).

\section{DISCUSSION}

The development of high density Alexandrium spp. populations in coastal areas has been reported worldwide (Gayoso 2001, Usup et al. 2002, Garces et al. 2004, McKenzie et al. 2004). In Ireland, Alexandrium spp. occur regularly along the coastline, but closures of 

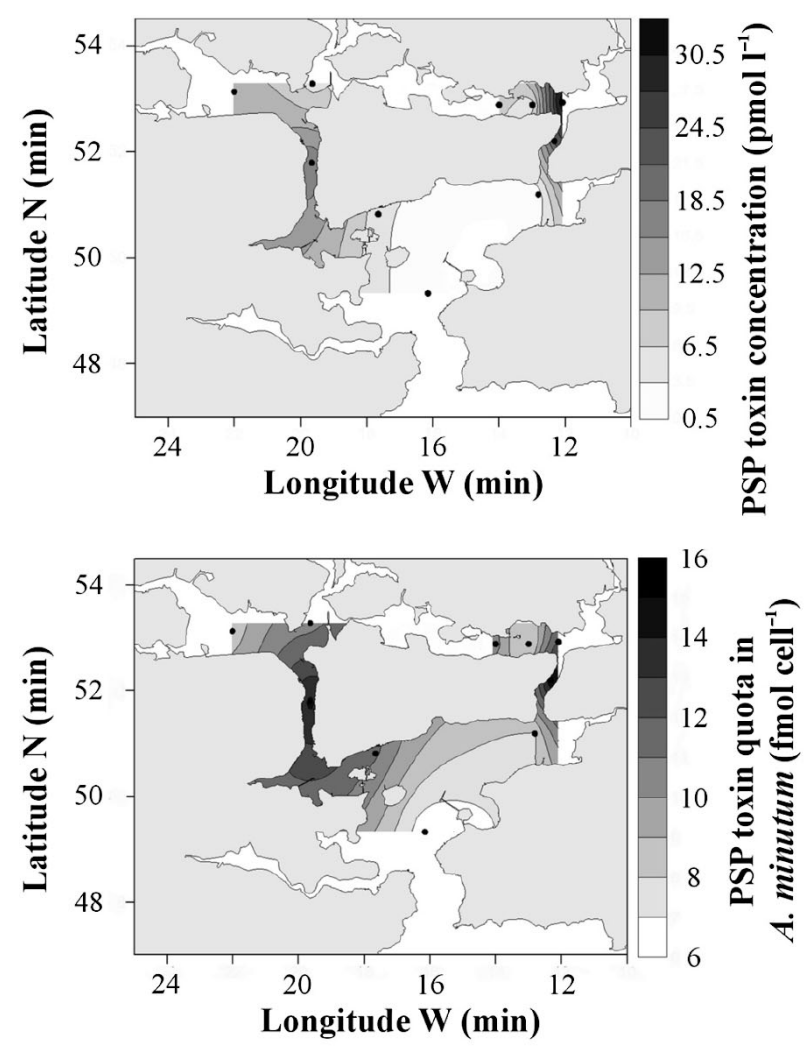
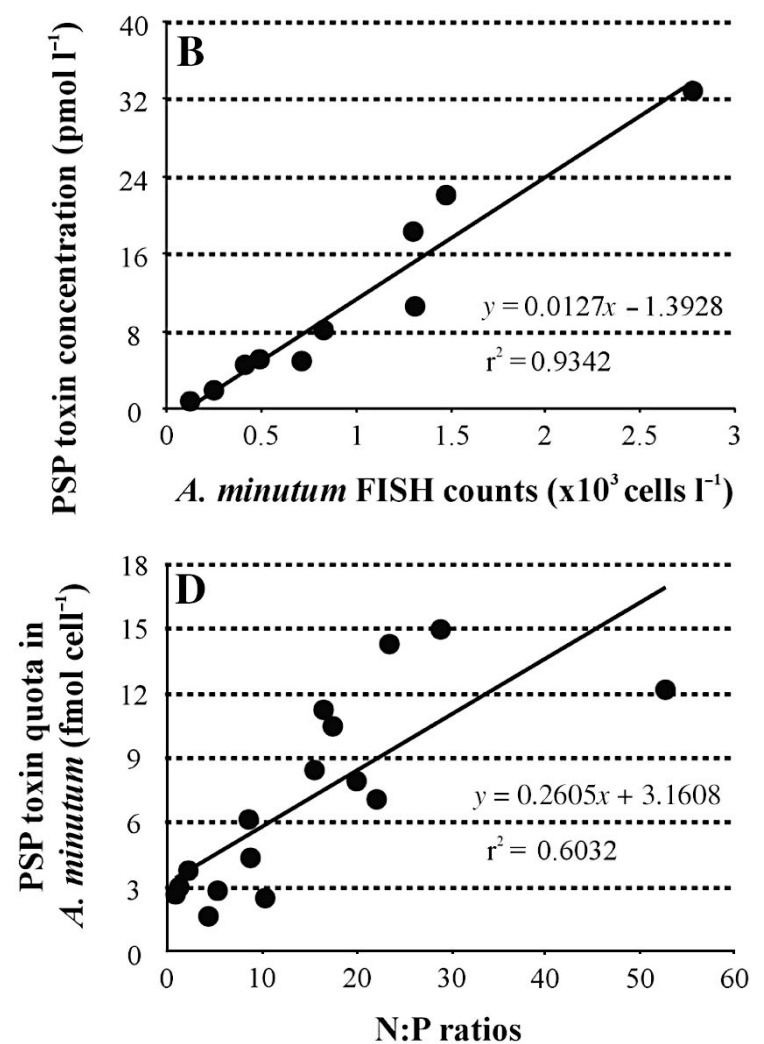

Fig. 8. (A) Surface concentrations of PSP toxins in Cork Harbour (ca. 51 $50^{\prime} \mathrm{N}, 8^{\circ} 17^{\prime} \mathrm{W}$ ) during the September survey and (B) relationship between FISH-derived Alexandrium minutum cell abundances and PSP toxin concentrations. (C) Areas where A. minutum cells appeared the most toxic, and (D) the positive relationship between cellular PSP toxin quotas and in situ N:P ratios after combining the July and September data

shellfish production sites due to contamination episodes with PSP toxins have only been localised along the south coast. Only recently were non-toxic A. tamarense and PSP toxin-producing $A$. minutum populations identified in Cork Harbour (Touzet et al. 2006), and knowledge on their distribution and relative contribution to the flora remains poor due to the inaccuracy of species identification by light microscopy. It is important from both ecological and monitoring viewpoints to understand their respective dynamics in relation to the biotic and abiotic environmental factors involved in the initiation, development and termination phases of blooms.

\section{Determination of Alexandrium spp. abundances}

The use of FISH for the detection and discrimination of morphologically similar HAB species has, along with the development of alternative molecular biology methods, been increasing over the last decade (Scholin et al. 1997, Rublee et al. 1999, John et al. 2003, Anderson et al. 2005). Although many parameters need consideration to ensure the success of rRNA-targeted
FISH probes, one particular region of the D1-D2 domain of the LSU rDNA has proved ideal for probe development (Kim et al. 2005). The probes MinA and TamA were designed in the vicinity of this $100 \mathrm{bp}$ long segment of the rDNA gene and tested with a range of cultured dinoflagellate species and water column field sample. The application of MinA and TamA FISH probes for the study of Alexandrium spp. in field samples from Cork Harbour allowed for fast and reliable discrimination between $A$. minutum and $A$. tamarense. Cell counts on $13 \mathrm{~mm}$ diameter membranes were performed much faster than those carried out with traditional light microscopy techniques. Additionally, confusion of Alexandrium spp. with Scrippsiella spp., Gonyaulax spp. or Protoperidinium spp. was avoided. Furthermore, the reliability of the analysis was enhanced with the concomitant use of calcofluor and DAPI on the same filter, which permitted the confirmation of the probes' diagnostics when some cells or cellshaped debris showed unusual background autofluorescence. The concentration of field samples from 21 to $15 \mathrm{ml}$ also allowed repeat examinations and could have enabled the specific detection of additional phytoplankton species by using different probe sets 

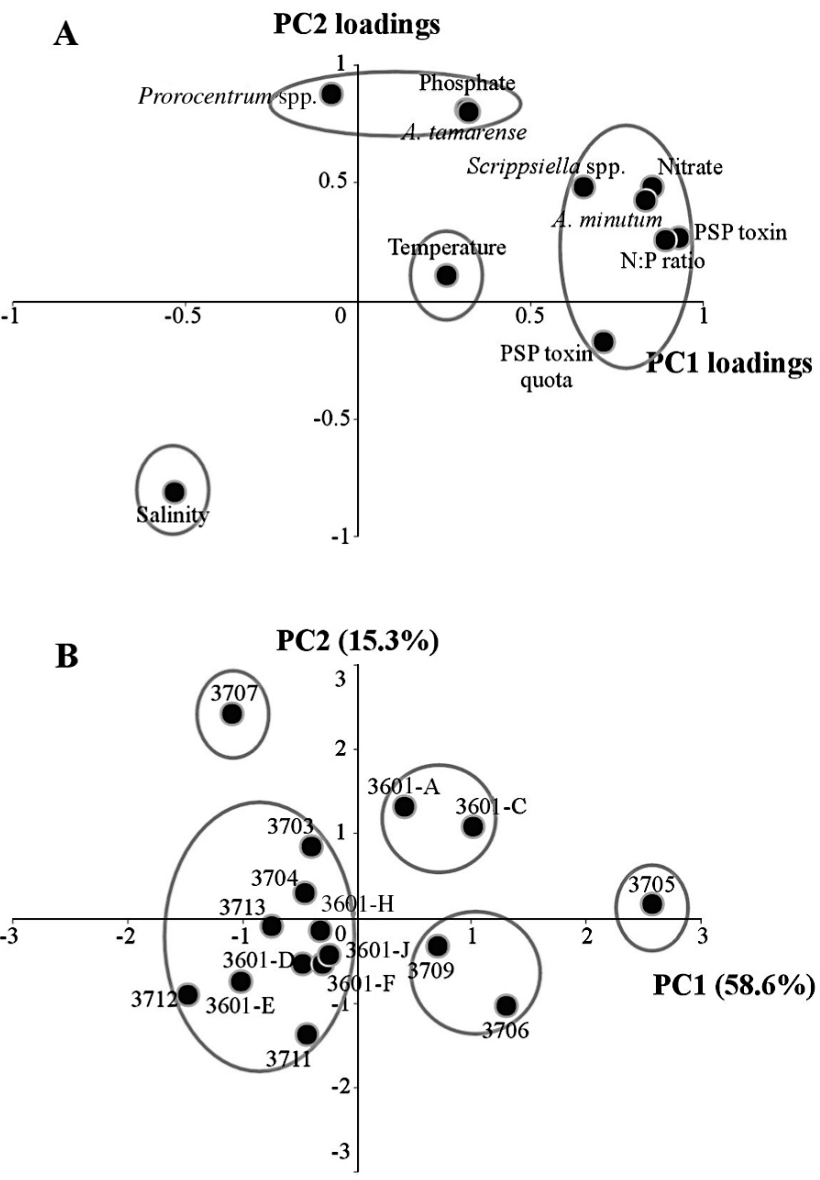

Fig. 9. Results of the multiple factor analysis showing the projections of the (A) variables and (B) samples on the plane defined by $\mathrm{PC} 1$ and $\mathrm{PC} 2$

since only small sample fractions were required for the hybridisation assays.

Some flaws in the quantitative analysis were, however, visible when FISH results were compared with those derived using the Utermöhl method carried out on non-concentrated taxonomic samples with calcofluor. FISH counts consistently gave underestimates (by a factor of $\sim 1.8$ ), results comparable with other studies on naturally occurring Alexandrium spp. populations (John et al. 2003, Anderson et al. 2005). The most obvious explanation is the loss of Alexandrium spp. cells when seawater samples were filtered through the ca. $80 \mathrm{~cm}^{2} 10 \mu \mathrm{m}$ mesh sieve. This surface area may have been too large to ensure the full recovery of the biological material after backwashing and/or some cells may have been damaged through the process. Some A. minutum cells, generally 2 to 3 times smaller than $A$. tamarense cells, may also have been forced through the mesh with the water flow. This could explain why $A$. minutum relative proportions obtained in July were lower with the whole-cell FISH method; the loss of $A$. minutum cells during the filtration process could also have contributed to the significantly greater underestimation factor observed between FISH- and Utermöhl-derived counts in September. The possibility that differences in cell counts derived from unlabelled target cells or from the presence of other Alexandrium species in the sample is, however, highly unlikely. During sample examination, hybridised samples were simultaneously scanned with calcofluor and the analyses showed that all Alexandrium spp. cells present on membranes were fluorescently tagged with MinA or TamA, even though some variability in the strength of the fluorescent signal was visible. One particular sample in September showed a major discrepancy between the 2 counting methods. The Alexandrium spp. concentration at Stn 3705 was apparently underestimated by a factor of 6 using the whole-cell FISH method. Anderson et al. (1999) reported that the signal intensity of the probe labelling could vary significantly according to the physiological state of cells using A. fundyense maintained in various culture conditions. Although this finding is also likely to apply to wild specimens, an underestimation of target cells through the omission of weakly labelled ones could not have occurred since the scanning of the entire membrane was performed using calcofluor to confirm the probes' diagnostics. It is most likely that a difference of such magnitude was attributable to bad sample homogenisation or leaks during sample collection and processing. Cell lysis through the filtration process may also have occurred but as the high discrepancy between the FISH- and Utermöhl-derived counts was observed only once, and seeing that Alexandrium spp. are armoured dinoflagellates, this is unlikely. Improvements of the recovery of Alexandrium spp. cells in field samples are necessary. Nevertheless, the field sample processing methodology used greatly facilitated the identification and quantification of Alexandrium spp. in Cork Harbour, where the richness in dinoflagellates morphologically similar to Alexandrium such as Scrippsiella, Glenodinium, Gonyaulax or Protoperidinium makes the examination of seawater samples by classic light microscopy a long and laborious task. Although the whole-cell FISH analysis of Alexandrium spp. is quicker and provides more reliable specimen identification than light microscopy, the current inaccuracies inherent to the method still prevent its implementation by regulatory and monitoring authorities. Methodological adjustments are required and the use of $47 \mathrm{~mm}$ diameter filters (5 $\mathrm{mm}$ mesh size) may prove more appropriate. This, however, could increase risks of clogging as, on occasion, high amounts of particulate matter were present, presumably resuspended by wind-driven and tidal currents in the shallow parts of the estuary. 


\section{PSP toxin analysis of field material}

Because of the potent suite of PSP toxins Alexandrium minutum can synthesise and its extended distribution along the Mediterranean and Atlantic European coastline, several studies have recently focused on characterising populations using morphological, biochemical and genetic approaches (Hansen et al. 2003, Lilly et al. 2005). Cultured strains isolated from geographically separated populations have shown different toxin profiles and degrees of toxicity according to the relative contribution of each toxic variant (Chang et al. 1997). In Ireland, previous studies have shown that annual occurrences of shellfish toxicity with PSP toxins in Cork Harbour were most likely attributable to $A$. minutum, whose toxin profile contained GTX3 and GTX2 only, with traces of their respective decarbamoyl forms (Furey et al. 1998, Touzet et al. 2006). PSP toxin analyses carried out on field samples collected for this study confirmed the stability of the toxin profile and showed positive correlations between $A$. minutum and PSP toxin concentrations. Previous investigations have suggested the use of toxin profiles as biochemical population markers (Franco et al. 1994), and GTX3 and GTX2 clearly appear as good indicators of the presence of $A$. minutum in Cork Harbour. Recent studies have reported the production of neurotoxic PSP-like toxins by Prorocentrum minimum (Sierra-Beltrán et al. 2005); however, the possibility that other phytoplankton species may contribute to PSP toxicity in Cork Harbour seems unlikely as the toxin profile obtained from field samples appears identical to that derived from local A. minutum strains (Touzet et al. 2007a).

Intracellular PSP toxin quotas were estimated using the Alexandrium minutum cell concentrations derived at each station with the whole-cell FISH method, since samples for toxin analysis had been collected using the same procedure. The average quotas derived in July and September were similar to the values obtained using cultured strains isolated from Cork Harbour and maintained in $\mathrm{f} / 2$ medium (Touzet et al. 2007a). Due to the composition of its toxin profile, which included the moderately toxic GTX2 and GTX3, the A. minutum population present in Cork Harbour appeared less toxic than those which synthesise more toxic variants, as observed with strains from Spain or New Zealand (Chang et al. 1997). Some variability was observed in the toxin quotas and this may partly be due to inaccuracies derived from the combination of low cell and toxin concentrations in some samples and the detection limits of the analytical equipment. Nonetheless, $A$. minutum cells present in the 2 narrow channels connecting Lough Mahon and the North Channel to the main harbour contained significantly higher amounts of PSP toxins. This may have been a reflection of stress-related effects as some studies have suggested that increases in PSP toxins could be linked with variations in environmental factors (Hwang \& Lu 2000, Lippemeier et al. 2003, Frangopulos et al. 2004). The 2 channels separate different water bodies and correspond to sites where cells may experience physiological stress, as rapid changes in temperature and salinity associated with turbulence may be expected from bottleneck effects and strong tidal currents.

Previous investigations have shown that variations of environmental and nutritional parameters could affect growth rates, trigger processes involved in life cycle transitions and influence PSP toxin composition and concentration of Alexandrium spp. (Anderson et al. 1984, Cembella 1998, Parkhill \& Cembella 1999). Several studies have shown the effects of phosphorus depletion on A. minutum intracellular PSP toxin quotas in batch culture, which have reached values greater than $20 \mathrm{fmol} \mathrm{cell}^{-1}$ (Chang et al. 1997, Béchemin et al. 1999, Lippemeier et al. 2003, Touzet et al. 2007b). For this study, the maximum PSP toxin quotas were observed in samples collected in the 2 connecting channels $\left(\sim 14 \mathrm{fmol} \mathrm{cell}^{-1}\right)$ and were associated with in situ N:P ratio values near 25 . The direct comparison of such values with those derived in the laboratory would be open to criticism, but the results obtained with the natural population of $A$. minutum from Cork Harbour seem to support the existence of a positive relationship between intracellular PSP toxin contents and in situ $\mathrm{N}: \mathrm{P}$ ratios. Results from the multivariate analysis carried out on the 2 data sets seem to corroborate this as the MFA highlighted for Cork Harbour a possible association between $A$. minutum, PSP toxins and in situ N:P ratios. In the future, the analysis of Alexandrium spp. internal nitrogen and phosphate pools may provide more valuable information on the physiological status of developing populations, as has been shown by Maestrini et al. (2000) using A. minutum cultures maintained in various $\mathrm{N}: \mathrm{P}$ regimes. However, the use of species-specific antibodies coupled to immunomagnetic techniques may be necessary to sort and isolate $A$. minutum vegetative cells from complex field sample matrices (Aguilera et al. 1996).

\section{Ecological considerations}

Some spatio-temporal variability was apparent in the distribution and abundance of Alexandrium spp. during the 2 surveys. Although $A$. minutum was present at all the stations sampled, its abundance was maximal in the North Channel. Laboratory experiments using batch cultures under a suite of various environmental conditions have shown that $A$. minutum strains iso- 
lated from Cork Harbour have lower maximum specific growth rates than A. tamarense (N. Rathaille, N. Touzet \& R. Raine unpubl. data). This may explain why A. minutum patches develop mainly in the North Channel, the region of the harbour with a higher residence time where the dilution effects due to tidal currents and the neap/spring phase succession would be attenuated (Ní Rathaille 2007). This, in turn, allows the constitution of $A$. minutum resting cyst beds (>500 cysts $\mathrm{cm}^{-3}$ dry weight sediments) which can support the local developments of vegetative cell patches at bloom times in the area (Ní Rathaille 2007).

Proliferations of bloom-forming species in marine coastal environments partly depend on the nutrient status of an area and the specific requirements of individual organisms (Glibert et al. 2005). For both surveys, the highest concentrations of Alexandrium spp. and selected armoured dinoflagellates were found in embayed zones where nutrient supplies were enhanced by freshwater run-offs. The in situ N:P ratios (excluding the contribution of dissolved ammonium) were inferior to the optimal Redfield ratio of 16 in July and greater in September, indicating probable nitrogen-limiting conditions and sufficiency, respectively (Redfield 1958). Some common trends are apparent when comparing the A. minutum situation in Cork Harbour with that found in other European countries where toxic populations also develop. Similar to the North Channel, Arenys de Mar (Catalan coast, Spain) and Syracuse (Sicily, Italy) harbours are embayed sites subjected to A. minutum blooms (Vila et al. 2005). These areas are also under the influence of riverine freshwater run-offs that can provide abundant nutrients, including dissolved organic carbon substances such as humic acids (Gagnon et al. 2005). Another similarity between the 3 locations resides in the composition of the phytoplankton assemblages associated with A. minutum, which mainly include Prorocentrum spp. and Scrippsiella spp.

Phytoplankton samples are periodically taken for monitoring of $\mathrm{HAB}$ species near shellfish production sites in the North Channel of Cork Harbour throughout the year. Tide-related variation of cell densities along with natural patchiness in the distribution of Alexandrium spp. may explain why discrepancies were observed between the Alexandrium spp. cell concentrations obtained during this study with those concomitantly derived by the monitoring agency, which are obtained from light microscopy analysis. To assist monitoring bodies in managing HAB events, the development of predictive biophysical models has been implemented for some harmful species (McGillicuddy et al. 2005, Blauw et al. 2006). Considering Cork Harbour and Alexandrium spp., a good understanding of the oceanography of the area as well as detailed knowledge on the biology of both A. minutum and A. tamarense is required for valid model parameterisation.

\section{CONCLUSIONS}

The taxon-specific oligonucleotide probes MinA and TamA greatly facilitated the study of the distribution and abundance of the co-occurring species Alexandrium tamarense and A. minutum in Cork Harbour. Quantitative work is traditionally problematic in the field because of issues in differentiating between species with classic microscopy methods. Given that $A$. minutum has been identified as the possible PSP toxinproducing organism in this region and that great variability was observed in the abundance and distribution of both species during the 2 surveys, molecular probes are essential tools for the better understanding of the ecology of Alexandrium spp. in Cork Harbour and adjacent areas. However, although FISH probes permitted fast identification and enumeration of target cells in field samples, traditional counts using fluorescence microscopy with calcofluor will still, at least temporarily, be necessary for species-specific identification and further calibrations of whole-cell FISH assays. Few studies have focused on the natural variability of PSP toxin composition and concentration in natural populations. Results obtained during the September survey in Cork Harbour showed a greater cellular toxicity in areas where fluctuations of environmental variables such as temperature, salinity and turbulence can happen quickly. These will need further confirmation and require the analysis of field samples collected when A. minutum reaches bloom concentrations in the area.

Acknowledgements. The authors thank D. Hugh-Jones, B. Byrne and D. Geary for the use of their on-site facilities and the provision of boats. Thanks to H. Farrell, S. Lyons and A. Ní Rathaille for laboratory analyses and assistance in field work. This work was supported by the Higher Education Authority of Ireland (PRTLI Cycle III) and by the EC 6th Framework Programme through the SEED project (GOCECT-2005-003375).

\section{LITERATURE CITED}

Aguilera A, Gonzales-Gil S, Keafer BA, Anderson DM (1996) Immunomagnetic separation of cells of the toxic dinoflagellate Alexandrium fundyense from natural plankton samples. Mar Ecol Prog Ser 143:255-269

Andersen P, Enevoldsen H, Anderson DM (2003) Harmful algal monitoring programme and action plan design. In: Hallegraeff GM, Anderson DM, Cembella AD (eds) Manual on harmful marine microalgae. UNESCO, Paris, p 627-647 
Anderson DM (1998) Physiology and bloom dynamics of toxic Alexandrium species, with emphasis on life cycle transitions. In: Anderson DM, Cembella AD, Hallegraeff GM (eds) Physiological ecology of harmful algal blooms. NATO AS1 Series, Vol G41. Springer-Verlag, Berlin, p 29-48

> Anderson DM, Kulis DM, Orphanus JA, Ceurvels AR (1984) Sexuality and cyst formation in the dinoflagellate Gonyaulax tamarensis. J Phycol 20:418-425

Anderson DM, Kulis DM, Keafer BA, Berdalet E (1999) Detection of the toxic dinoflagellate Alexandrium fundyense (Dinophyceae) with oligonucleotide and antibody probes: variability in labelling intensity with physiological condition. J Phycol 35:870-883

Anderson DM, Kulis D, Keafer BA, Gribble KE, Marin R, Scholin CA (2005) Identification and enumeration of Alexandrium spp. from the Gulf of Maine using molecular probes. Deep-Sea Res II 52:2467-2490

Balech E (1995) The genus Alexandrium Halim (Dinoflagellata). Sherkin Island Marine Station Publication, Sherkin Island, Co. Cork

Béchemin C, Grzebyk D, Hachame F, Hummert C, Maestrini SY (1999) Effect of different nitrogen/phosphorus nutrient ratios on the toxin content in Alexandrium minutum. Aquat Microb Ecol 20:157-165

Blauw AN, Anderson P, Estrada M, Johansen M and others (2006) The use of fuzzy logic for data analysis and modeling of European harmful algal blooms: results of the HABES project. Afr J Mar Sci 28:365-369

Cembella AD (1998) Ecophysiology and metabolism of paralytic shellfish toxins in marine microalgae. In: Anderson DM, Cembella AD, Hallegraeff GM (eds) Physiological ecology of harmful algal blooms. NATO ASI Series, Vol G41. Springer-Verlag, Berlin, p 381-403

Chang FH, Anderson DM, Kulis DM, Till DG (1997) Toxin production of Alexandrium minutum (Dinophyceae) from the Bay of Plenty, New Zealand. Toxicon 35:393-409

Escofier B, Pages J (1990) Analyses factorielles simples et multiples: objectifs, methodes, interpretations. Dunod, Paris

FAO (2004) Marine biotoxins. FAO food and nutrition paper, 80. FAO, Rome

Franco JM, Fernandez Vila P (1993) Separation of paralytic shellfish toxins by reversed phase high performance liquid chromatography with postcolumn reaction and fluorimetric detection. Chromatographia 35:613-620

Franco JM, Fernandez P, Reguera B (1994) Toxin profiles of natural populations and cultures of Alexandrium minutum Halim from Galician (Spain) coastal waters. J Appl Phycol 6:275-279

Frangopulos M, Guisande C, de Blas E, Maneiro I (2004) Toxin production and competitive abilities under phosphorus limitation of Alexandrium species. Harmful Algae 3:131-139

Fritz L, Triemer RE (1985) A rapid simple technique utilizing Calcofluor White M2R for the visualization of dinoflagellate thecal plates. J Phycol 21:662-664

Furey A, James KJ, Sherlock IR (1998) First report of paralytic shellfish poisoning toxins in the Republic of Ireland. In: Reguera B, Blanco J, Fernandez ML, Wyatt T (eds) Harmful algae. Xunta de Galicia and IOC of UNESCO, Santiago de Compostela, p 70-71

Gagnon R, Levasseur M, Weise AM, Fauchot J and others (2005) Growth stimulation of Alexandrium tamarense (Dinophyceae) by humic substances from the Manicouagan River (Eastern Canada). J Phycol 41:489-497

Galluzzi L, Penna A, Bertozzini E, Vila M, Garces E, Magnani
M (2004) Development of a real-time PCR assay for rapid detection and quantification of Alexandrium minutum (a dinoflagellate). Appl Environ Microbiol 70:1199-1206

- Garces E, Bravo I, Vila M, Figueroa RI, Maso M, Sampedro N (2004) Relationship between vegetative cells and cyst production during Alexandrium minutum bloom in Arenys de Mar harbour (NW Mediterranean). J Plankton Res 26: $637-645$

Garcia C, Del Carmen Bravo M, Lagos M, Lagos N (2004) Paralytic shellfish poisoning: post-mortem analysis of tissue and body fluid samples from human victims in the Patagonia fjords. Toxicon 43:149-158

> Gayoso AM (2001) Observations on Alexandrium tamarense (Lebour) Balech and other dinoflagellate populations in Golfo Nuevo, Patagonia (Argentina). J Plankton Res 23: 463-468

Glibert PM, Anderson DM, Gentien P, Graneli E, Sellner KG (2005) The global, complex phenomena of harmful algal blooms. Oceanography (Wash DC) 18:136-147

Gribble KE, Keafer BA, Quilliam MA, Cembella AD, Kulis DM, Manahan A, Anderson DM (2005) Distribution and toxicity of Alexandrium ostenfeldii (Dinophyceae) in the Gulf of Maine, USA. Deep-Sea Res II 52:2745-2763

Hallegraeff GM (1993) A review of harmful algal blooms and the apparent global increase. Phycologia 32:79-99

Hallegraeff GM (2003) Harmful algal blooms: a global overview. In: Hallegraeff GM, Anderson DM, Cembella $\mathrm{AD}$ (eds) Manual on harmful marine microalgae. UNESCO, Paris, p 25-49

> Hansen G, Daugbjerg N, Franco JM (2003) Morphology, toxin composition and LSU rDNA phylogeny of Alexandrium minutum (Dinophyceae) from Denmark, with some morphological observations on other European strains. Harmful Algae 2:317-335

Hoagland P, Anderson DM, Kaoru Y, White AW (2002) The economic effects of harmful algal blooms in the United States: estimates, assessment issues, and information needs. Estuaries 25:819-837

> Hwang DF, Lu YH (2000) Influence of environmental and nutritional factors on growth, toxicity, and toxin profile of dinoflagellate Alexandrium minutum. Toxicon 38: 1491-1503

John U, Cembella A, Hummert C, Elbrachter M, Groben R, Medlin L (2003) Discrimination of the toxigenic dinoflagellates Alexandrium tamarense and A. ostenfeldii in cooccurring natural populations from Scottish coastal waters. Eur J Phycol 38:25-40

Kao CY (1993) Paralytic shellfish poisons. In: Falconer IR (ed) Algal toxins in seafood and drinking waters. Academic Press, London, p 75-86

Kim CJ, Kim CH, Sako Y (2005) Development of molecular identification method for genus Alexandrium (Dinophyceae) using whole-cell FISH. Mar Biotechnol 7: 215-222

Lilly EL, Halanych KM, Anderson DM (2005) Phylogeny, biogeography, and species boundaries within the Alexandrium minutum group. Harmful Algae 4:1004-1020

Lippemeier S, Frampton DMF, Blackburn SI, Geier SC, Negri AP (2003) Influence of phosphorus limitation on toxicity and photosynthesis of Alexandrium minutum (Dinophyceae) monitored by in-line detection of variable chlorophyll fluorescence. J Phycol 38:320-331

Luckas B, Hummert C, Oshima Y (2003) Analytical methods for paralytic shellfish poisons. In: Hallegraeff GM, Anderson DM, Cembella AD (eds) Manual on harmful marine microalgae. UNESCO, Paris, p 191-209

MacKenzie L, deSalas M, Adamson J, Beuzenberg V (2004) 
The dinoflagellate genus Alexandrium (Halim) in New Zealand coastal waters: comparative morphology, toxicity and molecular genetics. Harmful Algae 3:71-92

Maestrini SY, Béchemin C, Grzebyk D, Hummert C (2000) Phosphorus limitation might promote more toxin content in the marine invader dinoflagellate Alexandrium minutum. Plankton Biol Ecol 47:7-11

McGillicuddy DJ Jr, Anderson DM, Lynch DR, Townsend DW (2005) Mechanisms regulating large-scale seasonal fluctuations in Alexandrium fundyense populations in the Gulf of Maine: results from a physical-biological model. DeepSea Res II 52:2698-2714

Miller PE, Scholin CA (1998) Identification and enumeration of cultured and wild Pseudo-nitzschia (Bacillariophyceae) using species-specific LSU rRNA-targeted fluorescent probes and filter-based whole cell hybridization. J Phycol 34:371-382

Moran S, Silke J, Salas R, Chamberlan T and others (2005) Review of phytoplankton and environmental monitoring 2004. Proc 5th Irish Shellfish Safety Workshop, Rosscarbery, 28 October 2004, Mar Environ Health Ser 19:5-10

Ní Rathaille A (2007) Modelling Alexandrium bloom dynamics in Cork Harbour, Ireland. PhD thesis, National University of Ireland, Galway

Oshima Y, Sugino K, Yasumoto T (1989) Latest advances in HPLC analysis of paralytic shellfish toxins. In: Natori S, Hashimoto K, Ueno Y (eds) Mycotoxins and phycotoxins '88. Elsevier, Amsterdam, p 319-326

Parkhill JP, Cembella AD (1999) Effects of salinity, light and inorganic nitrogen on growth and toxigenicity of the marine dinoflagellate Alexandrium tamarense from northeastern Canada. J Plankton Res 21:939-955

Redfield AC (1958) The biological control of chemical factors in the environment. Am Sci 46:205-221

Rublee PA, Kempton J, Schaefer E, Burkholder JM, Glasgow HB Jr, Oldach D (1999) PCR and FISH detection extends the range of Pfiesteria piscicida in estuarine waters. Va J Sci 50:325-336

Scholin CA, Miller P, Buck K, Chavez F and others (1997)

Editorial responsibility: Douglas Capone,

Los Angeles, California, USA
Detection and quantification of Pseudo-nitzschia australis in cultured and natural populations using LSU rRNAtargeted probes. Limnol Oceanogr 42:1265-1272

- Sierra-Beltrán AP, Cortés-Altamirano R, Cortés-Lara MC (2005) Occurrences of Prorocentrum minimum (Pavillard) in México. Harmful Algae 4:507-517

> Sorokin YUI, Sorokin PYU, Ravagnan G (1996) On an extremely dense bloom of the dinoflagellate Alexandrium tamarense in lagoons of the Po river delta: impact on the environment. J Sea Res 35:251-255

Strickland JDH, Parsons TR $(1972)$ A practical handbook of seawater analysis. Bull 167, 2nd edn. J Fish Res Board Can, Ottawa

- Touzet N, Raine R (2007) Discrimination of Alexandrium andersoni and A. minutum (Dinophyceae) using LSU rRNA-targeted oligonucleotide probes and fluorescent whole-cell hybridization. Phycologia 46:168-177

Touzet N, Franco JM, Raine R (2006) Inter- and intra-specific variability in morphogenetics and toxin composition of Alexandrium spp. in Irish coastal waters. Afr J Mar Sci 28:181-184

Touzet N, Franco JM, Raine R (2007a) Characterization of nontoxic and toxin-producing strains of Alexandrium minutum (Dinophyceae) in Irish coastal waters. Appl Environ Microbiol 73:3333-3342

Touzet N, Franco JM, Raine R (2007b) Influence of inorganic nutrition on growth and PSP toxin production of Alexandrium minutum (Dinophyceae) from Cork Harbour, Ireland. Toxicon 50:106-119

> Usup G, Pin LC, Ahmad A, Teen LP (2002) Alexandrium (Dinophyceae) species in Malaysian waters. Harmful Algae 1:265-275

Utermöhl H (1958) Zur Vervollkommnung der quantitativen Phytoplankton Methodik. Mitt Int Ver Limnol 9:1-38

Vila M, Giacobbe MG, Maso M, Gangemi E and others (2005) A comparative study on recurrent blooms of Alexandrium minutum in two Mediterranean coastal areas. Harmful Algae 4:673-695

Submitted: June 7, 2007; Accepted: January 31, 2008

Proofs received from author(s): May 2, 2008 